\title{
Canlı donordan qaraciyər transplantasiyası: Azərbaycanda orqan köçürülməsi, etik məsələlər və donor seçimi
}

\author{
Nabil Seyidov ${ }^{1}$ \\ ${ }^{l}$ Sahiyya Nazirliyinin İctimai Sahiyya va İslahatlar Markazi, Leyla Medical Center
}

\begin{abstract}
Donor orqanların çatışmazlığı qaraciyər transplantasiyana məhdudiyyətlər yaradır. ABŞ-da, məsələn, hər il 6.000 qaraciyər transplantasiyası həyata keçirilir. Lakin, hər il 2.000-dən çox xəstə qaraciyər transplantasiyası almadığı üçün ölür. Canlı donordan qaraciyər transplantasiyası daha çox xəstəyə qaraciyərin köçürülməsi imkanı yaradır. Sol payın lateral seqmentinin canlı donordan alaraq resipiyentə köçürülməsi pediatrik xəstələrdə çox uğurlu nəticələr verir. Bəzi transplantasiya mərkəzlərində qaraciyərin sağ payının və daha az hallarda sol payının yaşlı donordan yaşlı resipiyentə köçürülməsi həyata keçirilir.

Canlı donordan qaraciyərin köçürülməsinin aşağıdakı üstünlükləri var: donorun geniş müayinəsi və ya skrininqinin aparılması (yararlığının yoxlanılması), transplantasiya əməliyyatı üçün ən optimal vaxtın təyin edilməsi və soyuq işemiya vaxtının qisa olması.

Bununla yanaşı canlı donordan qaraciyərin köçürülməsi (CDQK) həm də qaraciyərə ehtiyacı olan resipiyentlər arasında ölüm hallarının azalması (mortalite) ilə bağlıdır. Bu isə ölü donordan qaraciyəri gözləyərkən ölən xəstələrlə müqayisədə daha azdır.
\end{abstract}

Açar sözlor: hemofiliya, müalicə, tədqiqat.

\section{Azərbaycanda orqan transplantasiyasının inkişaf tarixinə qısa ekskurs.}

Azərbaycanda ilk orqan transplantasiyası faktı 1971-ci ildə qeydə alınmışdır. Akademik Mirməmməd Cavadzadə 1971-ci il martın 4-də nəinki Azərbaycanda, Cənubi Qafqazda və Yaxın Şərqdə ilk dəfə böyrək köçürülməsi əməliyyatını icra etmişdir. Sonradan bu nailiyyətə görə, o, 1974cü ildə SSRİ dövlət mükafatına layiq görülmüşdür. Mərhum akademikin rəhbərliyi ilə 1983-cü ilə kimi Azərbaycanda 30-a yaxın böyrəkköçürmə əməliyyatı aparılmışdır. Xüsusi ilə qeyd etmək lazımdır ki, böyrək donorlarının bir qismi beyin ölümü olan şəxslər yəni meyit donorları olmuşdur. $\mathrm{Bu}$ da bir tarixi faktdır ki, akademik Mirməmməd Cavadzadə 1971-ci ildə böyrək transplantasiyasını icra etdiyi zaman İran İslam Respublikası və Türkiyə Cumhuriyyəti kimi qonşu ölkələrdə transplantasiya oməliyyatları icra olunmurdu. Sovet hakimiyyətinin dağılması ərəfəsində yaranan durğunluq, tibbi avadanlıqların köhnəlməsi, işin risklilik dərəcəsinə görə onlar transplantasiya ilə məşğul olmamışlar. Müstəqillik qazandıqdan bir müddət sonra orqan transplantasiyası əməliyyatları xüsusəndə böyrək transplantasiyasına cəhd edildi. 2000-ci illərin əvvəllərində professor Kamal Abdullayevin rəhbərliyi ilə iranlı mütəxəssislərlə 20-yə yaxın böyrək transplantasiyası aparıld1. Lakın bu proses də davamiyyətsiz oldu. Çünki, transplantoloji əməliyyatları icra edən təhsilli yerli kadrların olmaması səbəbindən bu əməliyyatların icrası tam dayanmışdır. Bu sahədə işlərin bərpası Azərbaycanın müstəqillikdən sonrakı dövrdə müşahidə olunmuşdur. Orqan transplantasiyası ilə bağlı hüquqi bazanın formalaşdırılması Heydər Oliyevin dövrünə təsadüf edir. 1999-cu ildə "İnsan orqan və ya toxumalarının transplantasiyası haqqında" Azərbaycan Respublikasının qanunu qəbul olunmuş, 2000-ci ildə isə Nazirlər Kabinetinin qəbul etdiyi qərara görə, transplantasiyasina icazə verilən orqan və ya toxumaların siyahısı tutulmuşdur. Azərbaycan Respublikasında transplantologiyanın intibah dovrü 12.12.2008-ci ildə başladı. Bu tarixdə yəni 12.12.2008-ci ildə tibb üzrə fəlsəfə doktoru Mircəlal Kazımi Azərbaycan Respublikasında və Qafqazda ilk qaraciyər transplantasiyasını uğurla həyata keçirdib. Onun əməkləri sayəsində az bir 
müddət ərzində milli kadrlardan ibarət komanda formalaşıb. Tibb üzrə fəlsəfə doktoru Mircəlal Kazımi 2011-ci ildə böyrək transplantasiyasına da başladı. 2011-ci ildə Naxçıvan Muxtar Respublikasında ilk böyrək transplantasiyasını doktor Mircəlal Kazımi icra etmişdir. Onun rəhbərliyi altında 2019-cu ilə qədər 750-dən çox xəstəyə qaraciyər və böyrək transplantasiyası olundu. Azərbaycan Respublikasinda transplantologiya elminin və xidmətinin yaranması, inkişafı doktor Mircəlal Kazıminin əməyi nəticəsində olmuşdur.Bölgələrdə Quba, Qəbələ, Astara, Şirvan, Cəlilabad, Şamaxıda onlarla xəstəyə təmənnası olaraq böyrək transplantasiyasını icra edib. Doktor Mircəlal Kazıminin bu sahədə həkimlərin yetişməsində də əvəzsin rolu olmuşdur. Onun sayəsində transplantologiya və hepato-biliyar cərrahiyədə cərrah və rezidentlər təhsillərini artıraraq tibbin bu sahəsinə də yiyələnmişdirlər. Uşaqlara qaraciyər transplantasiyas1, uşaqlara

böyrək transplantasiyası, bir xəstəyə eyni anda həm böyrək həm də qaraciyər transplantasiyası ilk dəfə olaraq Mircəlal Kazımı tərəfindən icra olunub. Fəaliyyətinə görə ARDNŞ-1n fəxri fərmanına, Azərbaycan Respublikası Səhiyyə Nazirliyinin səhiyyə əlaçısı döş nişanı ilə təltif olunub.

\section{Canlı donordan qaraciyər transplantasiyası.}

Donor orqanların çatışmazlığı qaraciyər transplantasiyana məhdudiyyətlər yaradır. ABŞ-da, məsələn, hər il 6.000 qaraciyər transplantasiyası həyata keçirilir. Lakin, hər il 2.000-dən çox xəstə qaraciyər transplantasiyası almadığı üçün ölür. Canlı donordan qaraciyər transplantasiyası daha çox xəstəyə qaraciyərin köçürülməsi imkanı yaradır. Sol payın lateral seqmentinin canlı donordan alaraq resipiyentə köçürülməsi pediatrik xəstələrdə çox uğurlu nəticələr verir. Bəzi transplantasiya mərkəzlərində qaraciyərin sağ payının və daha az hallarda sol payının yaşlı donordan yaşlı resipiyentə köçürülməsi həyata keçirilir.

Canlı donordan qaraciyərin köçürülməsinin aşağıdakı üstünlükləri var:

- donorun geniş müayinəsi və ya skrininqinin aparılması (yararlığının yoxlanılması),

- transplantasiya əməliyyatı üçün ən optimal vaxtın təyin edilməsi və

- soyuq işemiya vaxtının qısa olması.

Bununla yanaşı canlı donordan qaraciyərin köçürülməsi (CDQK) həm də qaraciyərə ehtiyacı olan resipiyentlər arasında ölüm hallarının azalmas1 (mortalite) ilə bağlıdır. $\mathrm{Bu}$ isə ölü donordan qaraciyəri gözləyərkən ölən xəstələrlə müqayisədə daha azdır.

Düzdür, qeyd olunmalıdır ki, CDQK-i donor olan birisini risk altına qoymuş olur. ABŞ-da CDQK halları 2001-ci ildə zirvəyə çatmış, lakin 2002-ci ildə iki donorun ölümü səbəbindən əməliyyatlara maraq və onların sayı xeyli azalmışdır. 2001-c ildə ABŞ-da canlı donordan 519 qaraciyər transplantasiyası köçürülmüşdürsə, 2003-cü ildə bu rəqəm cəmmi 320 olub. $\mathrm{Bu}$ enmənin səbəbi isə əməliyyatın özü ilə bağlı potensial ağırlaşmalara dair narahatçılığın artması olmuşdur. Ümumiyyətlə isə 2004-cü ilədək ABŞ-da 1300-dən çox CDQKnin əməliyyatı aparılıb.

\section{Etik məsələlər}

Primum non nocere - tibbdə çox geniş tanınmış bir ifadədir. Onun mənası "ilk öncə zərər yetirmə" deməkdir və əsrlərdir ki, həkimlərin və ümumiyyətlə tibb işçilərinin inandiğı və dəstəklədiyi bir şüardır. İlk baxışdan canlı donordan qaraciyərin transplantasiyası "primum non nocere" baza prinsipini pozmuş görünür. Belə ki, sağlam olan birisi öna heç bir fiziki fayda verməyən və riskli cərrahi əməliyyata gedir.

Canlı donordan qaraciyərin transplantasiyası ilə bağlı etik narahatçılıqlar donor şəxsin xəstələnməsi və ölüm potensialı ilə bağlıdır. CDQK-nə qarşı çıxış edən mütəxəssislər hesab edir ki, sağlam şəxsdən qaraciyər donoru kimi istifadə edərək onun 
sağlamlığını risk altına qoymaq və ya ölüm riskini artırmaq qəbul edilməzdir. Sol pay və ya sol lateral seqmentin donorluğu əsasən pediatrik transplantasiyada istifadə edilir və $5-10 \%$ cərrahi ağırlaşmalar və $<1 \%$-dən az ölüm riski ilə bağlıdır (Bibl. istinad 6,7). Canlı yaşlıdan yaşlı xəstəyə qaraciyərin sağ payının donorluğu ilə bağlı mortalite isə $0.5 \%$ ətrafindadır.

Həmin risklərə baxmayaraq, CDQK-ni dəstəkləyən mütəxəssislər hesab edir ki, risklər barədə dolğun məlumatı olan və donor olmaq istəyən şəxsi bu imkandan məhrum etmək etik deyil. Maraqlıdır ki, potensial donorlar arasında aparılmış (Bibl. istinad 8) sorğudan molum olub ki, onlar hətta daha yüksək mortalite riski olsa belə donor olmaq istərdilər.

Pediatrik xəstələrdə isə valideynlər və ya digər yaxın ailə üzvləri uşağa yardım etmək üçün qaraciyər donoru qismində ç1xış edə bilər. $\mathrm{Bu}$ yanaşmanın resipiyentə olan faydası danılmazdır. Bununla yanaşı, donor da (valideynlər) resipiyentin (qaraciyər almış uşaq) sağalması və/və ya uzun müddət sağ qalmasından, habelə uşağının sağalmasında oynadığı rola görə özünə-inamın yüksəlməsindən bəhrələnmiş olur.

Yaşlilarda CDQK əlavə məsələlərin ortaya çıxmasına səbəb olur. CDQK-də iştirak edən potensial donorlar adətən sağlam və çox vaxt gənc yaşlı şəxslər olur. Yaxın qohumlar arasında qan qrupu və s. meyarları uyğun gələn potensial donor şəxsin üzərinə böyük yük düşmüş olur. Həmçinin, həyat yoldaşının (ər və ya arvad) donor olması əlavə risklərlə bağlıdır. Belə ki, həyat yoldaşının donor olmasını qəbul edərkən bilmək lazımdır ki, ağırlaşmaların baş verməsi və ya donorun ölməsi hallarında uşaqların kimsəsiz qalma riski mövcuddur.

Digər bir məsələ fulminant qaraciyər çatışmazlığı halları ilə bağlıdır. Belə ki, fulminant qaraciyər çatışmazlığı çox q1sa müddət ərzində qaraciyərin köçürülməsini tələb edir və bu cür hallarda potensial donoru ətraflı molumatlandırmaq və bütün suallarını cavablandırmaq üçün vaxt ya olmur, ya da çox az olur.

\section{Donorun seçilməsi}

Canlı donorlar adətən yaxın ailə üzvləri və ya həyat yoldaşları olur. Düzdür, bəzi ölkələrdə canlı donor kimi kənar şəxslər də qəbul edilir və onlar bəzən "anonim donorlar" adlanır. Birisinin donor seçilməsi çox ciddi prosesdir və ilk növbədə donorluğa namizədin tibbi və psixoloji yararlığı təyin edilməlidir. Donorların 21-55 yaş arası olmasına üstünlük verilməlidir. Həmçinin, donorların qaraciyər və ya digər yanaşı xəstəlikləri, o cümlədən, ürək-damar və beyin-damar xəstəliyi olmamalıdır. Yüngül sistem xəstəliklərinin olması (məs., nəzarətdə olan şəkərli diabet, yüngün hipertenziya) isə donorluğa mütləq əksgöstəriş hesab edilmir. Yüksək piylənmə dərəcəsi və ya BKI $>35$ olan şəxslər donorluqdan istisna edilməlidir. $\mathrm{Bu}$ qrup şəxslərdə postoperativ ağırlaşmaların baş vermə riski xeyli yüksəkdir. Piylənməsi olan şəxslərdə qaraciyərin steatozu (qaraciyər piylənməsi) da geniş yayılmışdır və bu köçürülməsi düşünülən potensial qraftın funksiyasina mənfi təsir göstərə bilər. Ümumiyyətlə, qaraciyər steatozuna şübhə olan donorlarda qaraciyər biopsiyasının aparılması tələb olunur. Bəzi mərkəzlərdə qaraciyər biopsiyası bütün potensial donorlarda aparılır.

Donor olmaq istəyən şəxslərin ciddi psixo-sosial müayinəsi aparılmalıdır.

ABO qan qrupu üzrə uyğunluğu olan və yaşı $<60$ dan aşağı donorlara üstünlük verilir. Donorun yaşına görə $\mathrm{CDQK}$-nin nəticələrini müqayisə etdikdə (yaşı <50-dən aşağı və yaşı $>50$ yuxarı olan donorlar) məlum olur ki, donorun yaşı ağırlaşmaların baş verməsinə az təsir göstərir. Lakin, yaşı $>50$-dən yuxarı olan donorlar arasında orta qaraciyər venasının (middle hepatic vein) götürülməsi ilə aparılan sağ hepatektomiya və ya qaraciyərin donorluğu nəticəsində donorda qaraciyər həcminin $<35 \%$-dən az qalması ciddi 
ağırlaşmalarla bağlı olur.

$\mathrm{ABO}$ qan qrupu üzrə uyğun gəlməyən şəxslərin canlı donor kimi istifadəsini təmin etmək üçün xüsusi desensitizasiya protokolları tərtib edilmişdir. Bir transplantasiya mərkəzində $\mathrm{ABO}$ qan qrupu uyğun olmayan 142 xəstə və $A B O$ qan qrupu uyğun gələn 960 xəstənin iştirak etdiyi klinik tədqiqatdan məlum olmuşdur ki, ümumi nəticələr (qraftın davamlılı̆̆ 1 və xəstənin sağ qalma müddəti) eyni olsa da,ABO qan qrupu uyğun olmayan resipiyentlərdə diffuz qaraciyərdaxili öd axarlarının daralması (strikturalar) daha çox müşahidə edilir.

Canlı donordan qaraciyərin köçürülməsi planlaşdırıldıqda, ilk addım kimi canlı donordan orqan köçürülməsinin riskləri barədə donoru və resipiyenti məlumatlandırmaq lazımdır. Çalışmaq lazımdır ki, məlumatlı razılıq bütün hallarda əldə edilsin və formal olmasın. Həmçinin potensial donora bütün risklər barədə düşünmək və öz istəyi ilə orqan köçürülməsindən imtina etmək üçün kifayət qədər vaxt verilməlidir. Adətən, donoru və resipiyenti iki müxtəlif həkimlər komandası təqib edir. $\mathrm{Bu}$ həm də donor və ya resipiyentin əks komandanın potensial təzyiqi ilə üzləşməməsi baxımından vacibdir.

Donorun tibbi müayinəsi aşağıdakılardan ibarətdir:

- Anamnezin toplanması: ətraflı anamnez və fiziki müayinə.

\section{- Laborator müavinolor:}

- biokimyəvi analizlər və qanın ümumi analizi, o cümlədən: koaquloqram, protein $\mathrm{C}$, antitrombin İi̇, faktor V, VİI və VIïì, C-reaktiv zülal, tiroid vəzinin funksional paneli (TSH, T3, T4).

- qaraciyər fermentlori,

- Hepatit B virusu (HBsAg, anti-HBcAb, antiHBsAb), Hepatit C virusu (anti-HCV Ab) və PZR ilə HIV-ə yoxlanma,

- Narkotik və psixotrop maddələrin qeyri-qanuni istifadəsinə dair yoxlanma.
- Olavə seroloji müayinələr: sitomeqalovirusa qarşı İgG və İgM, Herpes simplex virusu, Ebsteyin-Barr virusuna qarşı İgG və İgM, sifilisə görə VDRL testi.

- Instrumental vo diaqnostik müayinolori:

- Döş qəfəsinin rentgen filmi və EKQ.

- KT və ya MRT görüntüləməsi: sol lateral seqment və ya sağ payın həcminin müəyyən edilməsi ilə onun kütləsinin resipiyent üçün yararlı olduğunun dəyərləndirilməsi üçün KT və ya MRT görüntüləməsi aparılır. KT və ya MRT həm də donorun qaraciyərində hər hans1 patoloji ocaqların və ya törəmələrin olub olmadı̆̆ını müəyyən etmək və steatozun dərəcəsini təyin etmək üçün də istifadə edilir. MRT isə bununla yanaşı preoperativ xolangioqramın əldə edilməsi üçün çox faydalı qeyri-invaziv metoddur.

- KT və ya MRT vasitəsilə köçürülməsi planlaşdırılan qaraciyər payının həcmi təyin edilir. Bu məqsədlə, məsələn, qaraciyərin sağ payının həcmini müəyyən etmək üçün radioloq orta qaraciyər venası müəyyən edir və onun sağ payın sol hüdudu kimi götürür. Xüsusi kompüter proqramı vasitəsilə qaraciyərin həcmi və çəkisi təyin olunur. Bunun əsasənda GBWR və ya qraftın bədən çəkisinə olan nisbəti təyin edilir.

- Bir çox mərkəzlərdə KTA və ya MRTA (angioqrafiya) həm də donorun abdominal damarlarının görüntüləməsi üçün istifadə edilir. MRTA və ya KTA bu baxımdan ənənəvi angioqrafiyadan daha az invazivdir və kifayət qədər məlumatlidır. Angioqrafiya edildikdə adətən portal faza ilə qarın kötüyünün (coeliac truncus, qarın arteriyası) angioqrafiyası aparılır.

○ Öd yollarının anatomiyasını öyrənmək üçün ERXP-nin (endoskopik retroqrad xolangiopankreatoqrafiya) aparılması tövsiyə edilmir. ERXP-nin ağırlaşma riskləri yüksəkdir. Və MRA və ya KTA əlçatan olan mərkəzlərdə ERXP-nin aparılması məqsədə uyğun hesab 
edilmir. Bununla yanaşı əksər mütəxəssislər əməliyyatdaxili

(intraoperativ)

xolangioqrafiyanın aparılmasını mütləq hesab edir.

Bəzi xəstələrlə bağlı isə daha genişləndirilmiş ürək və ağciyər müayinələrinin aparılması tələb oluna bilər.

- Bir sira mərkəzlərdə qaraciyər biopsiyası donorun müayinəsinin tərkib hissəsidir. Digər mərkəzlərdə isə qaraciyər biopsiyası yalnız qaraciyər fermentlərinin səviyyəsi yüksək olan və ya steatoza şübhə olan potensial donorlarda aparılır. Ümumiyyətlə, donorun qaraciyər histologiyasının dəyərləndirilməsi üçün biopsiyanın istifadəsi 201 sağlam potensial donorun iştirakı ilə aparılmış tədqiqatda öz faydasını təsdiq etmişdir (Bibl. istinad 18). Maraqlıdır ki, həmin tədqiqatda iştirak etmiş sağlam potensial donorların $50 \%$-də biopsiya nəticəsində aşağıdakı patoloji dəyişikliklər müəyyən edilmişdir: steatoz, steatohepatit və həmçinin fibroz, hepatit və qranulomatoz reaksiyalar. Ümumiyyətlə isə qaraciyər biopsiyasında müəyyən edilmiş steatoz dərəcəsi qaraciyər kütləsinin həcmini dəqiqləşdirməyə imkan verir.

Müəyyən edilmiş donordan əldə ediləcək qaraciyər kütləsinin resipiyent üçün adekvat olmasını təyin etmək üçün GBWR (graft to body weight ratio) və ya qraftın bədən çəkisinə olan nisbəti təyin edilir. QBÇN (qraftın bədən çəkisinə olan nisbəti) minimum $>0.8 \%$ olan qraftların köçürülməsi tövsiyə edilir. Qeyd olunmalıdır ki, QBÇN $<0.8 \%$ dən aşağı olduqda, resipiyentlərdə "kiçik ölçülü qraft sindromunun" inkişafi riski yüksək olar. "Kiçik ölçülü qraft sindromu" assit, sarılıq və qaraciyərin durğunluğu ilə xarakterizə olunur. Düzdür, sağ qaraciyər payının köçürülməsi hallarında (săg hepatektomiya) "kiçik ölçülü qraft sindromu" çox nadir hallarda baş verir.

Digər bir tədqiqatdan məlum olmuşdur ki, potensial donorların çox kiçik bir hissəsi nəticədə donor olmağa yararlı olur. Belə ki, 700 potensial donorun iştirakı ilə aparılmış tədqiqatın nəticəsində müəyyən edilmişdir ki, onların cəmi 14\%-1 qaraciyər donorluğuna yararlıdır (Bibl. istinad 19). Digər bir tədqiqatda (A2ALL) isə müayinə edilmiş 1011 potensial donorun cəmi 40\%-1 donor olmağa qəbul edilmişdir. Potensial donor kimi qəbul edilməyə təsir göstərən amillər isə donorun cavan olması, bədən kütlə indeksinin aşağı olması və donorun resipiyentə yaxın qohumluğu və ya bioloji yaxınlığının olmasıdır.

Maliyyə Mənbəyi: Məqalənin hazırlanmasında heç bir kənar maliyyə mənbəyindən istifadə edilməyib.

Maraqların toqquşması: Qeyd edilməyib.

\section{ӘDӘBIYYYAT:}

1. Malagó M, Rogiers X, Broelsch CE. Liver splitting and living donor techniques. Br Med Bull 1997; 53:860.

2. Berg CL, Gillespie BW, Merion RM, et al. Improvement in survival associated with adultto-adult living donor liver transplantation. Gastroenterology 2007; 133:1806.

3. Northup PG, Abecassis MM, Englesbe MJ, et al. Addition of adult-to-adult living donation to liver transplant programs improves survival but at an increased cost. Liver Transpl 2009; 15:148.

4. Lai JC, Pichardo EM, Emond JC, Brown RS Jr. Resource utilization of living donor versus deceased donor liver transplantation is similar at an experienced transplant center. Am J Transplant 2009; 9:586.

5. Pomfret EA, Fryer JP, Sima CS, et al. Liver and intestine transplantation in the United States, 1996-2005. Am J Transplant 2007; 7:1376.

6. Grewal HP, Thistlewaite JR Jr, Loss GE, et al. Complications in 100 living-liver donors. Ann Surg 1998; 228:214.

7. Whitington PF. Living donor liver transplantation: ethical considerations. J Hepatol 1996; 24:625.

8. Cotler SJ, McNutt R, Patil R, et al. Adult living donor liver transplantation: Preferences about donation outside the medical community. 
Liver Transpl 2001; 7:335.

9. Vila G, Nollet-Clémençon C, de Blic J, et al. Assessment of anxiety disorders in asthmatic children. Psychosomatics 1999; 40:404.

10. American Society of Transplant Surgeons' position paper on adult-to-adult living donor liver transplantation. Liver Transpl 2000; 6:815.

11. Hashikura Y, Kawasaki S, Miyagawa S, et al. Donor selection for living-related liver transplantation. Transplant Proc 1997; 29:3410.

12. Dayangac M, Taner CB, Yaprak O, et al. Utilization of elderly donors in living donor liver transplantation: when more is less? Liver Transpl 2011; 17:548.

13. Chan SC, Lo CM, Yong BH, et al. Paired donor interchange to avoid ABO-incompatible living donor liver transplantation. Liver Transpl 2010; 16:478.

14. Hwang S, Lee SG, Moon DB, et al. Exchange living donor liver transplantation to overcome $\mathrm{ABO}$ incompatibility in adult patients. Liver Transpl 2010; 16:482.

15. Song GW, Lee SG, Hwang S, et al. Dual living donor liver transplantation with $\mathrm{ABO}$ incompatible and $\mathrm{ABO}$-compatible grafts to overcome small-for-size graft and $\mathrm{ABO}$ blood group barrier. Liver Transpl 2010; 16:491.

16. Song GW, Lee SG, Hwang S, et al. Biliary stricture is the only concern in ABOincompatible adult living donor liver transplantation in the rituximab era. J Hepatol 2014; 61:575.

17. Emond JC. Clinical application of liverrelated liver transplantation. Gastroenterol Clin North Am 1993; 22:301.

18. Savas N, Coskun M, Bilezikci B, et al. Value of an individual liver biopsy in the preoperative evaluation of apparently healthy potential liver donors. Liver Transpl 2008; 14:541. 